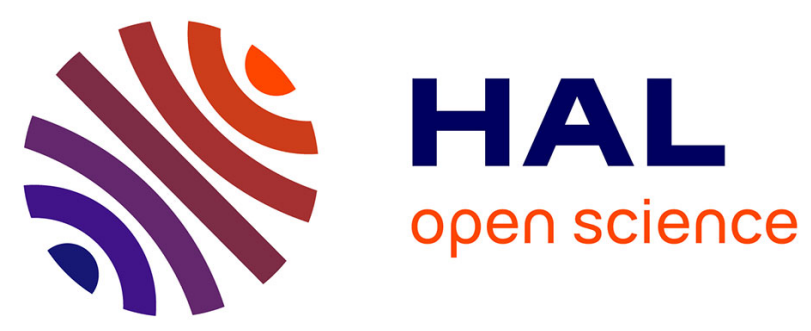

\title{
Artificial reefs do increase secondary biomass production: mechanisms evidenced by stable isotopes
}

Pierre Cresson, S. Ruitton, Mireille Harmelin-Vivien

\section{To cite this version:}

Pierre Cresson, S. Ruitton, Mireille Harmelin-Vivien. Artificial reefs do increase secondary biomass production: mechanisms evidenced by stable isotopes. Marine Ecology Progress Series, 2014, 509, pp.15-+. 10.3354/meps10866 . hal-01433604

\section{HAL Id: hal-01433604 \\ https://hal.science/hal-01433604}

Submitted on 10 May 2021

HAL is a multi-disciplinary open access archive for the deposit and dissemination of scientific research documents, whether they are published or not. The documents may come from teaching and research institutions in France or abroad, or from public or private research centers.
L'archive ouverte pluridisciplinaire $\mathbf{H A L}$, est destinée au dépôt et à la diffusion de documents scientifiques de niveau recherche, publiés ou non, émanant des établissements d'enseignement et de recherche français ou étrangers, des laboratoires publics ou privés. 


\title{
Artificial reefs do increase secondary biomass production: mechanisms evidenced by stable isotopes
}

\author{
Pierre Cresson $^{1,2,3, *}$, Sandrine Ruitton ${ }^{1,2}$, Mireille Harmelin-Vivien ${ }^{1,2}$ \\ ${ }^{1}$ Aix-Marseille Université, CNRS/INSU, IRD, Mediterranean Institute of Oceanography (MIO), UM 110, 13288 Marseille, France \\ ${ }^{2}$ Université de Toulon, CNRS/INSU, IRD, Mediterranean Institute of Oceanography (MIO), UM 110, 83957 La Garde, France \\ ${ }^{3}$ Present address: IFREMER, Laboratoire Environnement \& Ressources Provence-Azur-Corse, \\ Zone Portuaire de Brégaillon, BP 330, 83507 La Seyne sur Mer Cedex, France
}

\begin{abstract}
Artificial reefs (ARs) are used worldwide as a tool to manage and restore marine coastal ecosystems and to support small-scale fisheries, as increases in fish biomass around them commonly occur. Whether ARs actually produce biomass, or only attract fish from natural zones, is strongly debated. Using stable isotope ratios to elucidate the trophic organization of the largest Mediterranean artificial reef system, the present work demonstrates that the studied ARs effectively support biomass production, as invertebrate species directly depended on locally produced organic matter $(\mathrm{OM})$. OM of pelagic origin was the main source of matter due to the predominance of filter-feeder organisms on the ARs, while benthic primary production was of secondary importance. Isotopic ratios of fishes confirmed the importance of the ARs as a food supplier. Their position in the trophic network was consistent with the hypothesis proposing the effective ability of ARs to increase fish biomass through production mechanisms. Carbon and nitrogen stable isotope ratios provided a basis for achieving an integrative view of trophic relationships and food web functioning of ARs. This work constitutes a baseline for future work on efficient management of coastal zones, including natural and artificial reefs.
\end{abstract}

KEY WORDS: Attraction-Production - Coastal ecosystem - Mediterranean - Stable isotopes · Trophic functioning

Resale or republication not permitted without written consent of the publisher

\section{INTRODUCTION}

Fishing has always been a key activity for human subsistence and archeological records show that human tribes fished thousands of years ago. Nevertheless, with the development of industrial fisheries and the worldwide increasing demand for marine resources, overfishing has become one of the major threats altering the structure and functioning of marine ecosystems (Jennings \& Kaiser 1998, Pauly et al. 1998, Jackson et al. 2001, Bănaru et al. 2010). Consequently, efficient policies are needed to limit fishing pressure on marine ecosystems and to secure the sustainability of fish resources. In coastal zones, artificial reefs (ARs) within marine protected areas are currently considered as an efficient tool to manage and support small-scale coastal fisheries and to restore natural habitats affected by anthropogenic impacts (Claudet \& Pelletier 2004, Seaman 2007, Tessier et al. 2014). The term 'artificial reefs' encompasses multiple definitions depending on their origin (waste material deposited haphazardly or specifically designed structures), their purpose (ecosystem restoration, leisure activities, professional fisheries or protection against illegal trawling) and local policies (Seaman \& Jensen 2000, Baine 2001). The most exhaustive definition describes ARs as 'submerged structures placed on the substratum (seabed) deliber- 
ately, to mimic some characteristics of a natural reef' (Jensen 1998). Fish biomass increases are generally observed in the vicinity of ARs, with a benefit for fisheries (Bombace et al. 1994, Charbonnel et al. 2002, Leitão 2013). Unlike other policies, coastal management based on ARs relies not only on limitation of fishing activity, but also on biomass enhancement. This could explain why ARs are generally well-accepted by fishermen and other stakeholders, with different perceptions of ARs by different stakeholders, depending on their objectives (Claudet \& Pelletier 2004, Ramos et al. 2007, Leleu 2012, Leleu et al. 2014).

Identifying the biological processes involved in this fish biomass increase is crucial in AR research. Three factors are generally considered: addition of new substratum, sheltering effect and enhancement of food resources (Bohnsack 1989, Harmelin \& Bellan-Santini 1997). The deployment of artificial structures creates new hard substrata where benthic prey can settle, increasing food resources (Steimle \& Ogren 1982, Relini et al. 2002, Leitão et al. 2007, Scarcella et al. 2011). The architectural complexity of artificial structures provides shelter from predation for low trophic-level organisms or species at a vulnerable life stage, and allows the presence of numerous species of all sizes (Gorham \& Alevizon 1989, Eklund 1997, Charbonnel et al. 2002, Gratwicke \& Speight 2005). Finally, over time, these structures become a mating, spawning and recruitment zone for fishes and could function as a source of propagules for adjacent natural zones (Gorham \& Alevizon 1989, Eklund 1997).

Despite a wealth of literature on these issues and identification of these 3 factors, no decisive evidence has been provided to solve the 'attraction vs. production' debate regarding the real functioning of ARs (Bohnsack 1989, Polovina 1989, Grossman et al. 1997, Lindberg 1997, Pitcher \& Seaman 2000, Powers et al. 2003, Brickhill et al. 2005 and references therein). On the one hand, the attraction hypothesis suggests that ARs function as a sink for existing individuals coming from adjacent natural zones (Bohnsack 1989, Polovina 1989). Following this hypothesis, no effective biomass production occurs on ARs, and their deployment has no effect on the biomass of the whole zone (i.e. natural rocky substrates and ARs). Over time, AR deployment may have a counterproductive effect, as lower production occurs in natural zones and fishermen concentrate on ARs (Grossman et al. 1997, Pitcher \& Seaman 2000). On the other hand, the production hypothesis states that ARs are effective producers of fish biomass, by favoring the recruitment of new individuals and enhancing growth, due to increased availability of food and shelter (Powers et al. 2003). In this case, ARs would be effective tools to support fisheries and restore natural rocky habitats by enhancing the total biomass of the whole zone. The 'attraction vs. production' debate was largely driven by the fact that ARs are mainly used as a tool to sustain fisheries. Understanding which hypothesis effectively governs the functioning of ARs is crucial for the efficient management of ARs and associated fisheries.

In their review regarding the 'attraction vs. production' debate, Brickhill et al. (2005) list some of the knowledge gaps in this topic. Most of them concern trophic relationships on ARs and the transfer of organic matter (OM) from producers to consumers. Brickhill et al. (2005) promote the use of chemical tracers such as carbon and nitrogen stable isotopes to link fish biomass with primary production on ARs, as numerous works demonstrate that this technique is well suited for studying marine food webs (e.g. Kang et al. 2008, Boecklen et al. 2011, Layman et al. 2012, Daigle et al. 2013). The isotopic ratios of a consumer are directly linked with those of its prey with a difference between them. This factor is relatively low for carbon $(\sim 1 \%)$. Consequently, the carbon isotopic ratio of a consumer is close to those of the OM sources it is depending on, and is used to trace them. In contrast, the nitrogen fractionation factor is higher (theoretically 3 to $4 \%$ per trophic level) and the isotopic ratio of nitrogen is commonly used as a proxy for trophic level (Post 2002). Stable isotope ratios of the diet are integrated in the tissues of a consumer within several months. The coupled use of carbon and nitrogen isotopic ratios allows a better understanding of the trophic position of all organisms involved in a food web, and gives an integrated view of the trophic functioning of an ecosystem.

Through the 'RECIFS PRADO' program, 400 ARs were deployed in a $2 \mathrm{~km}^{2}$ zone in the Bay of Marseille between 2007 and 2008 (NW Mediterranean Sea, France). This program represents the largest AR system in the Mediterranean (Charbonnel et al. 2011). It was designed to support small-scale fisheries and to restore degraded habitats. It was also a good opportunity to scientifically assess the trophic functioning of a coastal AR system. Papers dealing with trophic ecology applied to ARs are scarce. To our knowledge, only 2 studies use the integrative view possible through stable isotope analyses to understand the functioning of the whole trophic network of AR systems (Kang et al. 2008, Daigle et al. 2013). To date, most studies performed on AR trophic relationships were applied to particular fish species using stomach content analyses (Steimle \& Ogren 1982, Relini et al. 2002, Leitão et al. 2007, Castriota et al. 2012). Our work has thus 3 major objectives: (1) to identify the 
major OM sources fueling AR trophic networks, (2) to characterize the organization of the trophic networks established on ARs and (3) to use the integrative view offered by stable isotope analyses to add new insights in the attraction-production debate.

\section{MATERIALS AND METHODS}

\section{Sampling sites}

ARs were deployed between 20 and $30 \mathrm{~m}$ depth on a sandy bottom with Posidonia oceanica dead matte (underlying structure of $P$. oceanica meadows constituted of rhizomes and roots intermingled with sediments; Boudouresque et al. 2012) and close to natural rocky substrates of the coastline and the Frioul Archipelago (Fig. 1), covering a $2 \mathrm{~km}^{2}$ area. AR modules were arranged in 6 triangular-shaped structures called 'villages'. Sampling was performed on 2 large 'metal-basket' ARs deployed at similar depth ( 30 m) in the north (village V3) and in the south (village V6) of the deployment zone. Metal basket is the largest reef type (187 $\mathrm{m}^{3}, 6 \mathrm{~m}$ high) deployed in Marseille. Its basic modules are composed of a metal frame filled with concrete cubes and concrete piles. Architectural

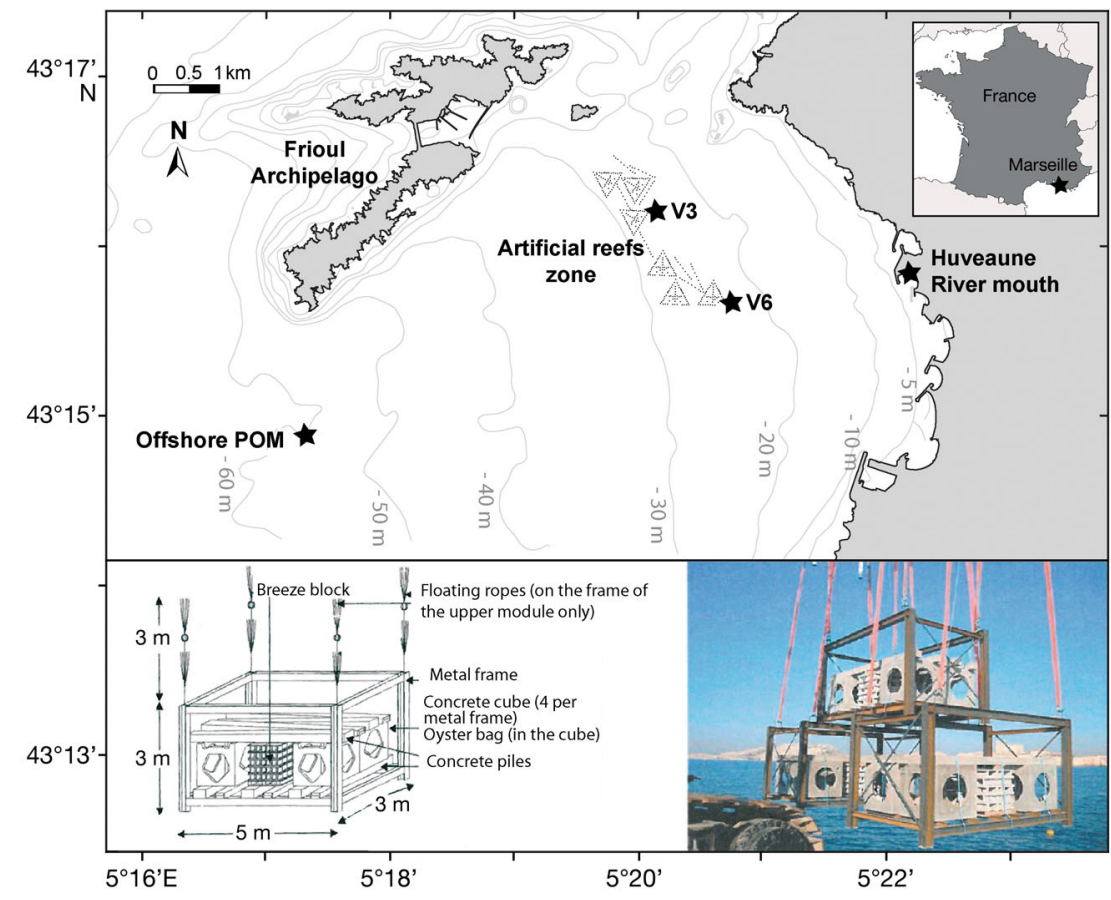

Fig. 1. Location of artificial reefs (AR) in the Bay of Marseille. Sampling sites are represented by the black stars (V3 and V6 artificial reefs, offshore particulate organic matter [POM], and Huveaune River). Sampling was done on 'metalbaskets' reefs, presented here as a sketch of the basic cubic module, and a picture of the AR during deployment (modified from Charbonnel et al. 2011) complexity of the module is increased by the addition of octopus pots, breeze blocks and bags filled with dead oyster shells (hereafter named 'oyster bags'). Such devices create additional shelters for numerous small invertebrates and allow sampling of cryptic species. At the time of sampling the AR zone was a full no-take zones with the possibility of being opened to small-scale coastal fisheries in a few years. For additional details on the design of the modules and the organization of the whole AR deployment zone, refer to Charbonnel et al. (2011).

\section{Sample collection}

All OM pools and producers potentially influencing AR trophic networks were sampled in spring, summer, autumn and winter 2010, to take into account their temporal variability. Particulate OM (POM) was sampled from subsurface seawater by filtering on preweighed GF/F Whatman filters precombusted to remove organic matter traces. Terrestrial inputs were taken into account by sampling POM brought to the sea by the Huveaune River. Additional isotopic data on nanophytoplankton (2 to $10 \mu \mathrm{m}$ ) and offshore POM (as a proxy for diatoms and dinobionts) were taken from bibliographical references (Rau et al. 1990, Darnaude et al. 2004). Sediment OM (SOM) was sampled by scraping the upper part of the sediment around ARs by SCUBA diving. More details on sampling procedures for OM pools are provided in Cresson et al. (2012). Benthic primary producers were also sampled seasonally by SCUBA diving. All macroalgal species observed were sampled. Samples of $P$. oceanica were also taken in the seagrass meadow located close to the AR zone. Back in the laboratory, all samples were rinsed, cleaned from epiphytes with razor blades, and identified at the species level. A total of 21 species of benthic producers were sampled and analyzed and are detailed in Table S1 in the Supplement at www. int-res.com/articles/suppl/m509p015_ supp.pdf.

Consumers (benthic invertebrates and fishes) were sampled during 2 campaigns in summer and winter 2010. Benthic invertebrates were collected manually or scraped off the AR by 
SCUBA diving. Small cryptic organisms were collected by sampling the oyster bag fauna. Analyses were run on the 22 species observed on the 2 ARs at both seasons. Macrobenthic invertebrate species were assigned to 5 trophic groups based on their diet and feeding habits (see Table S2 in the Supplement), following previous papers (e.g. Guerao 1995, Coma et al. 2001, Morton et al. 2007, Riisgård \& Larsen 2010, Schaal et al. 2012). Regarding a potential problem where a species may occur in 2 trophic groups, we do not believe it occurred here. We chose to define a species on the basis of its feeding mechanism; e.g. filtering, grazing or predation. The only problematic group may have been filter feeders, as they can retain some detritus and thus be considered as detritivores. But, as we considered the mechanisms, all filter feeders occur in the same group, regardless of the matter they retain.

Fishes were sampled by trammel net during scientific fishing campaigns or by spear fishing. A total of 325 individuals belonging to 23 species were kept for analyses. More details on the fish sampling are provided in Cresson et al. (2014). In the laboratory, invertebrates and fish were sorted and determined. The largest organisms were dissected to keep only muscle samples. For small organisms, several individuals were pooled to obtain enough material for analysis.

All samples (SOM, primary producers, invertebrates and fishes) were stored frozen, freeze dried and ground with an agate mortar and pestle before analysis. Prior to stable isotope analysis, all samples containing carbonates were acidified by adding $\mathrm{HCl}$ $1 \%$. As $\mathrm{HCl}$ treatment modifies nitrogen isotope ratios, samples were split in two; the acidified subsamble was used for $\delta^{13} \mathrm{C}$ determination and the untreated subsample for $\delta^{15} \mathrm{~N}$ determination.

\section{Stable isotope ratio measurement}

Stable isotope ratios were obtained with a continuous flow mass spectrometer (Delta V Advantage, Thermo Scientific). Results are expressed with the classical $\delta$ notation

$$
\delta X=\left(\frac{R_{\text {sample }}}{R_{\text {standard }}}-1\right) \times 10^{3}
$$

where $\left(X\right.$ is ${ }^{13} \mathrm{C}$ or ${ }^{15} \mathrm{~N}$ and $R$ the isotopic ratio ${ }^{13} \mathrm{C} /{ }^{12} \mathrm{C}$ or ${ }^{15} \mathrm{~N} /{ }^{14} \mathrm{~N}$, respectively). Standards were V-PDB for carbon and atmospheric $\mathrm{N}_{2}$ for nitrogen. Measurement precision was calculated from replicated measurements of acetanilide laboratory standard and is $<0.1 \%$. All analyses were run at least in triplicate for all samples.

\section{Statistical analyses}

Statistical analyses were run separately: (1) on OM sources and pools, (2) on invertebrates and (3) on fishes. Following the fate of OM sources in the trophic networks requires differences in their $\delta^{13} \mathrm{C}$ and $\delta^{15} \mathrm{~N}$ values. To this aim, mean annual values measured for each OM pool (terrestrial and marine POM, SOM) and benthic primary producers groups (rhodobionta, chromobionta, chlorobionta and the seagrass $P$. oceanica) were compared. Values for nano- and microphytoplankton available in the literature (Rau et al. 1990, Darnaude et al. 2004) were not included in this comparison. For invertebrates, seasonal differences were checked for each invertebrate species, by comparing mean $\mathrm{C}$ and $\mathrm{N}$ isotopic ratios of individuals sampled in summer and winter. Then, interspecific variations of isotopic ratios were assessed by comparing the mean annual values observed for each species. Finally, similarity between species was confirmed by hierarchical clustering analyses based on species annual average $\delta^{13} \mathrm{C}$ and $\delta^{15} \mathrm{~N}$, using Euclidean distance and Ward criterion. When needed, groups were refined using data on taxonomical proximity or previous knowledge regarding feeding groups. Analyses run on fishes were detailed in Cresson et al. (2014). Briefly, species were classified in different groups with a hierarchical clustering based on isotopic ratios, and refined with knowledge about diet and habitats. Their mean annual $\delta^{13} \mathrm{C}$ and $\delta^{15} \mathrm{~N}$ values were also compared. All comparison tests were performed with 1-way ANOVAs after checking for normality (Kolmogorov-Smirnov test) and homogeneity of variances (Levene test) and using Fisher's least square distance post-hoc test when ANOVA showed significant differences. Relationships between mean $\delta^{13} \mathrm{C}$ and $\delta^{15} \mathrm{~N}$ values observed for invertebrates and fishes were assessed by a linear regression. A significant relationship ( $\mathrm{p}<0.05$ ) between $\delta^{13} \mathrm{C}$ and $\delta^{15} \mathrm{~N}$ values measured for consumers generally indicates that they belong to the same trophic network. All analyses were performed with $\mathrm{R}$ software and the 'cluster' package (R Development Core Team 2012, Maechler et al. 2013).

\section{RESULTS}

\section{Isotopic ratios of $\mathrm{OM}$ pools and primary producers}

Comparison of annual mean values revealed significant differences between $\mathrm{OM}$ pools and sources for their $\delta^{13} \mathrm{C}\left(\mathrm{ANOVA}, F_{6,608}=112.0, \mathrm{p}<0.0001\right)$ and 
Table 1. Mean ( $\pm \mathrm{SD}) \delta^{13} \mathrm{C}$ and $\delta^{15} \mathrm{~N}$ isotopic ratios measured for groups used in the artificial reef trophic network. Trophic group: pp, primary producer; po, organic matter pool; de, detritivore; ff, filter feeder; gr, grazer; om, omnivore; fish; Fp, piscivorous fish. SOM: sediment organic matter; POM: particulate organic matter. Values for each species are detailed in Tables S1 \& S2 in the Supplement at www.int-res.com/articles/suppl/m509p015_supp.pdf

\begin{tabular}{|c|c|c|c|c|}
\hline Taxon & $\begin{array}{l}\text { Trophic } \\
\text { group }\end{array}$ & $\begin{array}{c}\text { No. of } \\
\text { species }\end{array}$ & $\delta^{13} \mathrm{C}(\%)$ & $\delta^{15} \mathrm{~N}(\%)$ \\
\hline Chlorobionta & $\mathrm{pp}$ & 4 & $-17.42 \pm 1.38$ & $4.41 \pm 0.42$ \\
\hline Posidonia oceanica & $\mathrm{pp}$ & 1 & $-15.44 \pm 1.03$ & $3.74 \pm 0.90$ \\
\hline Rhodobionta & $\mathrm{pp}$ & 7 & $-26.66 \pm 2.17$ & $3.63 \pm 0.22$ \\
\hline Chromobionta & $\mathrm{pp}$ & 10 & $-21.47 \pm 1.17$ & $3.66 \pm 0.29$ \\
\hline Nanophytoplankton $^{\mathrm{a}}$ & pp & - & $-25.23 \pm 1.16$ & $1.77 \pm 0.25$ \\
\hline Microphytoplankton $^{\mathrm{b}}$ & $\mathrm{pp}$ & - & $-22.70 \pm 0.76$ & $3.17 \pm 1.25$ \\
\hline SOM & po & - & $-21.95 \pm 0.57$ & $3.67 \pm 0.25$ \\
\hline POM & po & - & $-24.18 \pm 0.85$ & $5.13 \pm 0.90$ \\
\hline Riverine POM & po & - & $-26.25 \pm 0.51$ & $4.48 \pm 0.41$ \\
\hline Holoturia tubulosa & de & 1 & $-16.60 \pm 1.03$ & $7.55 \pm 0.41$ \\
\hline Bivalves & ff & 5 & $-21.67 \pm 1.25$ & $3.94 \pm 0.58$ \\
\hline Chaetopterus variopedatus & ff & 1 & $-22.17 \pm 1.09$ & $3.60 \pm 0.46$ \\
\hline Ascidians & ff & 3 & $-21.92 \pm 1.13$ & $5.52 \pm 0.58$ \\
\hline Gastropods & gr & 4 & $-19.16 \pm 1.10$ & $4.89 \pm 0.49$ \\
\hline Palinurus elefas & om & 1 & $-20.00 \pm 0.57$ & $5.76 \pm 0.81$ \\
\hline Palaemon sp. & pr & 1 & $-19.93 \pm 0.55$ & $7.44 \pm 0.46$ \\
\hline Other crustaceans & om & 6 & $-21.25 \pm 0.82$ & $5.77 \pm 0.57$ \\
\hline Echinaster sepositus & $\mathrm{pr}$ & 1 & $-18.91 \pm 2.74$ & $5.84 \pm 0.57$ \\
\hline Marthastarias glacialis & pr & 1 & $-17.17 \pm 0.53$ & $8.15 \pm 1.13$ \\
\hline Hexaplex trunculus & pr & 1 & $-17.94 \pm 0.49$ & $8.69 \pm 0.72$ \\
\hline Zooplankton-feeding fishes & $\mathrm{Fz}$ & 3 & $-19.75 \pm 0.37$ & $8.28 \pm 0.51$ \\
\hline Labrids & $\mathrm{FC}_{\mathrm{C}}$ & 3 & $-18.88 \pm 0.65$ & $9.49 \pm 0.49$ \\
\hline Macrocarnivores & $\mathrm{FC}_{\mathrm{C}}$ & 3 & $-17.91 \pm 0.50$ & $9.89 \pm 0.43$ \\
\hline Sandy-bottom mesocarniv. & $\mathrm{FC}_{\mathrm{C}}$ & 3 & $-17.89 \pm 0.58$ & $10.30 \pm 0.71$ \\
\hline Benthic piscivores & $\mathrm{Fp}$ & 3 & $-18.11 \pm 0.33$ & $10.30 \pm 0.53$ \\
\hline Diplodus spp. & $\mathrm{FC}_{\mathrm{C}}$ & 3 & $-18.59 \pm 1.00$ & $11.64 \pm 1.31$ \\
\hline Pelagic piscivores & $\mathrm{Fp}$ & 3 & $-18.71 \pm 1.73$ & $13.34 \pm 2.29$ \\
\hline
\end{tabular}
pr, predator; Fz, zooplankton-feeding fish; $\mathrm{FC}_{\mathrm{C}}$, benthic invertebrate-feeding

\section{Isotopic ratios of invertebrates}

Comparison of mean $\delta^{13} \mathrm{C}$ and $\delta^{15} \mathrm{~N}$ revealed strong isotopic differences $\left(\right.$ ANOVA $F_{45,854}=64.6, \mathrm{p}<0.0001$ for $\delta^{13} \mathrm{C}_{;}$ANOVA $F_{45,827}=244.0, \mathrm{p}<$ 0.0001 for $\delta^{15} \mathrm{~N}$ ) among all invertebrate species (Table 1, Fig. 2), encompassing a wide range of isotopic values $\left(6 \%\right.$ for $\delta^{13} \mathrm{C}, 5 \%$ o for $\left.\delta^{15} \mathrm{~N}\right)$. Invertebrates displayed heterogeneous isotopic ratios, consistent with different feeding strategies, the use of different food sources and the occupation of several trophic levels. Lowest $\delta^{13} \mathrm{C}$ and $\delta^{15} \mathrm{~N}$ were observed for species in the group of filter feeders (bivalves, ascidians, and the annelid Chaetopterus variopedatus). Values measured for filter-feeders except ascidians were lower than those measured for POM sampled on the ARs, but higher than those of nano- and microphytoplankton. Comparison of seasonal means revealed few significant differences (data not shown) for most of the species except filter feeders, which displayed systematically lower $\delta^{13} \mathrm{C}$ values in summer than in winter (Fig. 3). Except for Galathea intermedia and Palaemon sp., all crustaceans came within the same group due to close intermediate values (Fig. 4). The grazing gastropods exhibited a particular signature, with relatively low $\delta^{15} \mathrm{~N}$ but high $\delta^{13} \mathrm{C}$ val-

$\delta^{15} \mathrm{~N}\left(\right.$ ANOVA, $\left.F_{6,608}=28.7, \mathrm{p}<0.0001\right)$, allowing the use of stable isotope ratios to follow their fate in the trophic network (Table 1, Fig. 2). A wide range of $\delta^{13} \mathrm{C}$ values was recorded, the highest in Posidonia oceanica leaves $(-15.55 \pm 1.03 \%)$ and the lowest in rhodobionta $(-26.66 \pm 2.17 \%$ o). Values measured for chromobionta and SOM were not significantly different. Among OM pools and sources, POM $\delta^{15} \mathrm{~N}$ ratio $(5.13 \pm 0.90 \%)$ was significantly higher. The lowest $\delta^{15} \mathrm{~N}$ value of OM sources measured on the ARs occurred for rhodobionta $(3.63 \pm 0.22 \%$ ) and was not significantly different from those measured for SOM $(3.67 \pm 0.25 \%$ ) and chromobionta (3.66 $\pm 0.29 \%$ o). According to the literature (Rau et al. 1990, Darnaude et al. 2004), nano- and microphytoplankton exhibited even lower $\delta^{15} \mathrm{~N}$ values $(1.77 \pm 0.25 \%$ and $3.17 \pm 1.25 \%$, respectively). ues. Finally, despite using different feeding modes, 3 species belonged to the same group characterized by high $\delta^{13} \mathrm{C}$ and $\delta^{15} \mathrm{~N}$ values. The detritivore species Holoturia tubulosa exhibited high $\delta^{13} \mathrm{C}$ and $\delta^{15} \mathrm{~N}$ values, close to those measured for the predatory invertebrate species Marthasterias glacialis and Hexaplex trunculus.

\section{Isotopic ratios of fishes}

Detailed results on isotopic ratios of fishes were presented in Cresson et al. (2014). Thus, major information only is summarized below. The range of isotopic ratios measured in fishes was lower for $\delta^{13} \mathrm{C}$ ( $2 \%$ only), but higher for $\delta^{15} \mathrm{~N}$ (7\%) than in invertebrates, suggesting a lower diversity of carbon 


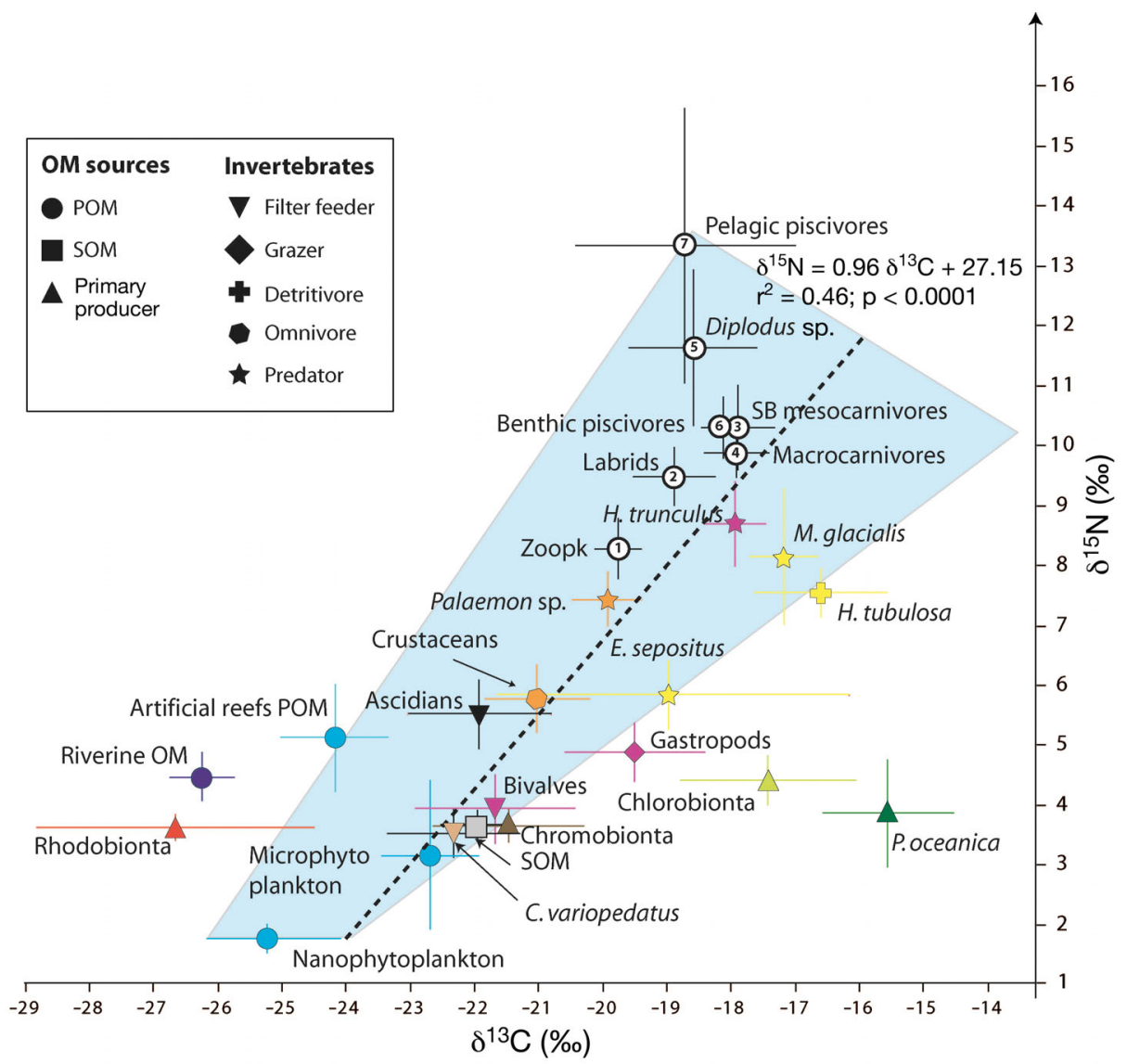

Fig. 2. Mean $( \pm \mathrm{SD})$ isotopic ratios $\left(\delta^{13} \mathrm{C}\right.$ and $\left.\delta^{15} \mathrm{~N}\right)$ of organic matter (OM) sources, invertebrates and fishes sampled on the artificial reefs. Symbols refer to the nature of the OM or the trophic mode of invertebrates. Groups of fish species are represented by empty circles. Colors stand for the taxonomic group of organisms (red: rhodobionta; brown: chromobionta; light green: chlorobionta; dark green: seagrass; purple: mollusks; orange: crustaceans; yellow: echinoderms; black: ascidians; white: fishes). The blue zone represents the influence of pelagic OM on trophic networks, the dashed line the $\delta^{13} \mathrm{C}$ versus $\delta^{15} \mathrm{~N}$ regression. SB: sandy-bottom; SOM: sediment organic matter; Zoopk: zooplankton-feeding fish. See Table 1 for species abbreviations

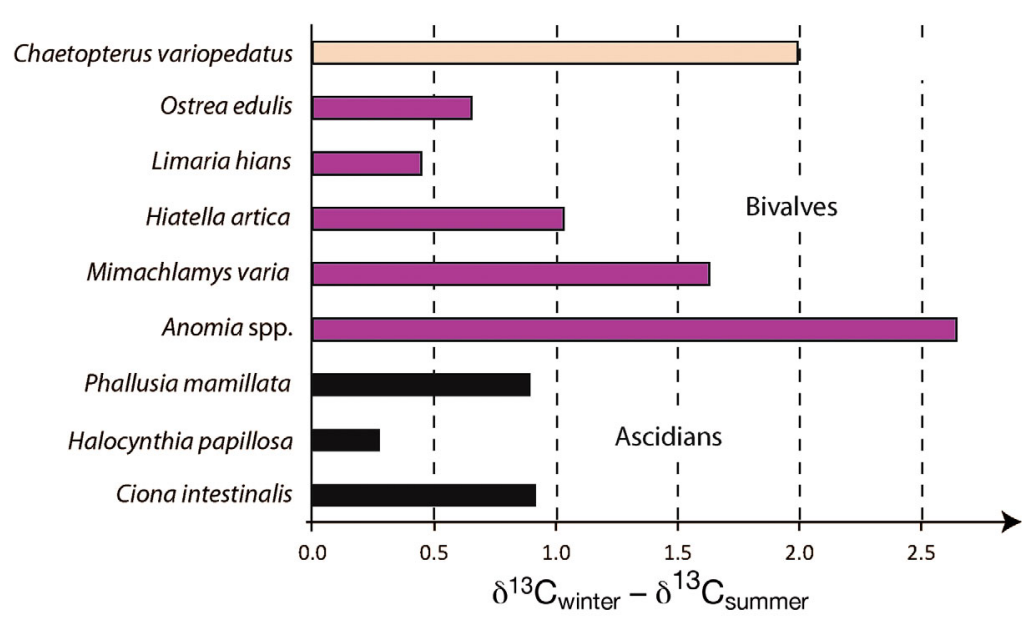

Fig. 3. Differences between $\delta^{13} \mathrm{C}$ values measured for filter feeders in summer and winter. Color code as in Fig. 2
(Fig. 2, Table S2 in the Supplement). The lowest isotopic ratios were measured for the group of zooplankton-feeding species (Boops boops, Spicara maena and $S$. smaris) and were consistent with their diet. Piscivores exhibited the highest $\delta^{15} \mathrm{~N}$ values and could thus be considered as the highest trophiclevel species on ARs, even if isotopic differences occurred between benthic (Phycis phycis, Synodus saurus and Scorpaena scrofa) and pelagic species (Dicentrarchus labrax, Sphyraena viridensis and Trachurus mediterraneus). Consequently, they belonged to 2 different groups of piscivores. The other species were separated within 4 groups, with intermediate isotopic ratios, and a diet based on invertebrates, mainly crustaceans. The 3 Diplodus species clustered apart from other sparids due to rather high $\delta^{15} \mathrm{~N}$ values. The position of fish groups on the $\delta^{13} \mathrm{C}$ versus $\delta^{15} \mathrm{~N}$ biplot (Fig. 2) indicated that all fish species fitted well into continuity of the position occupied by invertebrates in ARs trophic

network. This result was also consistent with the sig- sources, but stronger trophic differences. Fish species occupied at least 3 trophic levels on the ARs. Significant differences were observed in fish $\delta^{13} \mathrm{C}$ (ANOVA $\left.F_{22,522}=24.1 ; \mathrm{p}<0.0001\right)$ and $\delta^{15} \mathrm{~N}$ (ANOVA $\left.F_{22,522}=66.2 ; \mathrm{p}<0.0001\right)$ values. Fish species could be split into 7 groups, based on their isotopic ratios, diet and habitat (water column, soft or rocky bottom) 


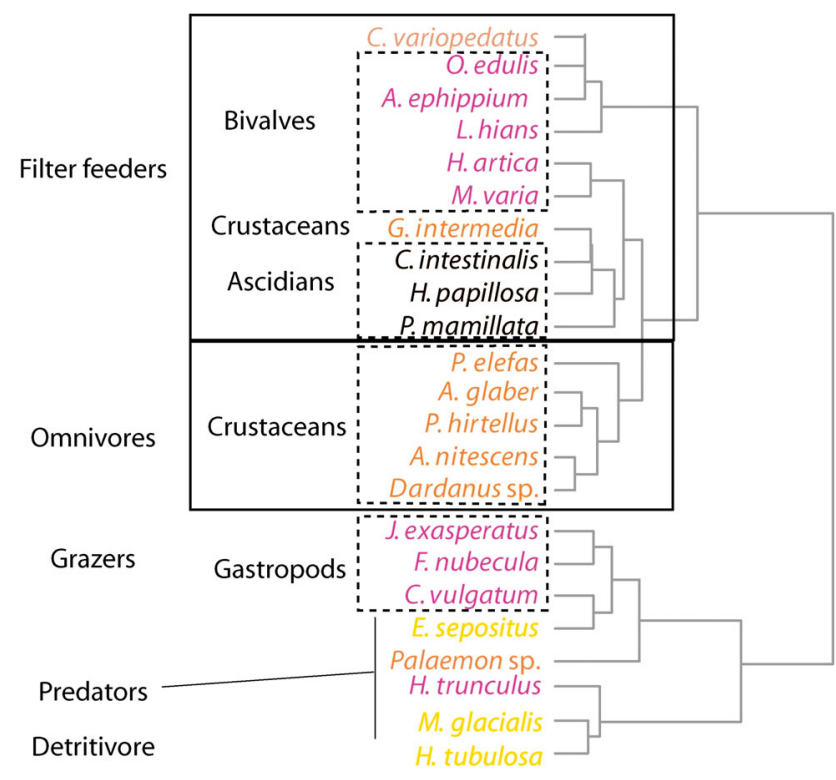

Fig. 4. Hierarchical clustering tree based on invertebrate isotopic $\delta^{13} \mathrm{C}$ and $\delta^{15} \mathrm{~N}$ values. Solid squares represent trophic groups. Dashed squares represent groups based on both stable isotope values and taxonomic data, and in use in Fig. 2 and Table 1. Colors represent the taxonomic groups of organisms and are the same as in Fig. 2

nificant correlation observed between $\delta^{15} \mathrm{~N}$ and $\delta^{13} \mathrm{C}$ of all consumers, invertebrates and fishes combined $\left(\delta^{15} \mathrm{~N}=0.96 \delta^{13} \mathrm{C}+27.15 ; \mathrm{r}^{2}=0.46, \mathrm{p}<0.0001\right)$, suggesting that most consumers belonged to the same trophic pathway, with fishes at its top.

\section{DISCUSSION}

Understanding how organic matter is used in an AR system has been demonstrated to be a crucial question to assess the actual mechanisms involved in its functioning (Brickhill et al. 2005, Leitão 2013). Isotopic ratios measured on AR organisms in the Bay of Marseille corroborate the hypothesis that 2 main pathways support secondary production on ARs, the 'pelagic pathway', based on the consumption of OM of pelagic origin, and the 'benthic pathway', based on local benthic production.

\section{OM fueling of the AR trophic network}

Isotopic ratios (Fig. 2) allowed the construction of a conceptual model of the AR trophic network, from organic matter sources up to fishes (Fig. 5). In natural ecosystems, carbon comes mainly from the use of pelagic $\mathrm{OM}$ and/or local benthic primary production (Fig. 6). These mechanisms are also involved in the functioning of AR systems. The topology of the model denoted the predominance of pelagic primary production as the main source of OM supporting the trophic network. Sessile filter feeders dominate in the fauna of the Marseille ARs (Rouanet et al. 2012). Due to their strong filtration abilities, they are mainly responsible for the increase in pelagic OM fluxes toward benthic communities. The low isotopic ratios measured for filter feeders confirmed their opportunistic diet and the preferential consumption of the main POM fraction (Coma et al. 2001). Nanophytoplankton is dominant in the Bay of Marseille in spring (Grégori et al. 2001) and represents a high amount of OM for filter feeders. This trend was confirmed by the lowest $\delta^{13} \mathrm{C}$ values recorded in summer for all filter feeders (Fig. 3). Due to the integration time, isotopic ratios measured in filter feeders sampled in summer reflect their diet in the past few months, and the high consumption of nanophytoplankton during the spring bloom.

New substrates can also be colonized by benthic micro- and macroalgae, and enhance the total amount of local benthic primary production available for benthic consumers. The occurrence of small benthic grazers on ARs (Cerithium vulgatum, Fissurela nubecula, or Jujubinus exasperatus) indicates that benthic primary production is directly consumed by herbivorous species. They exhibited particular isotopic signatures, with higher $\delta^{15} \mathrm{~N}$ than filter feeders, consistently with a diet based on benthic primary producers (Nadon \& Himmelman 2006). This benthic OM could also be used indirectly through the detrital pool, as confirmed by the similar isotopic ratios recorded between SOM and macroalgae, and previous results on SOM composition (Cresson et al. 2012). The use of drifted algal detritus to complement their diet was previously demonstrated for filter feeders (Schaal et al. 2012). Many crustaceans were also considered as partly detritivores. Furthermore, the high isotopic values measured for Holothuria tubulosa were consistent with its detritivorous feeding and the consumption of Posidonia oceanica dead leaf detritus, abundant in surface sediment (Cresson et al. 2012). Finally, higher amounts of benthic and pelagic OM trapped in the AR contribute to the increase of organic matter in sediment (SOM), and enhance bacterial recycling of OM.

The trophic position inferred from stable isotope ratios for organisms at higher trophic levels (invertebrates and fishes) demonstrated that AR biomass production is able to support a whole trophic 


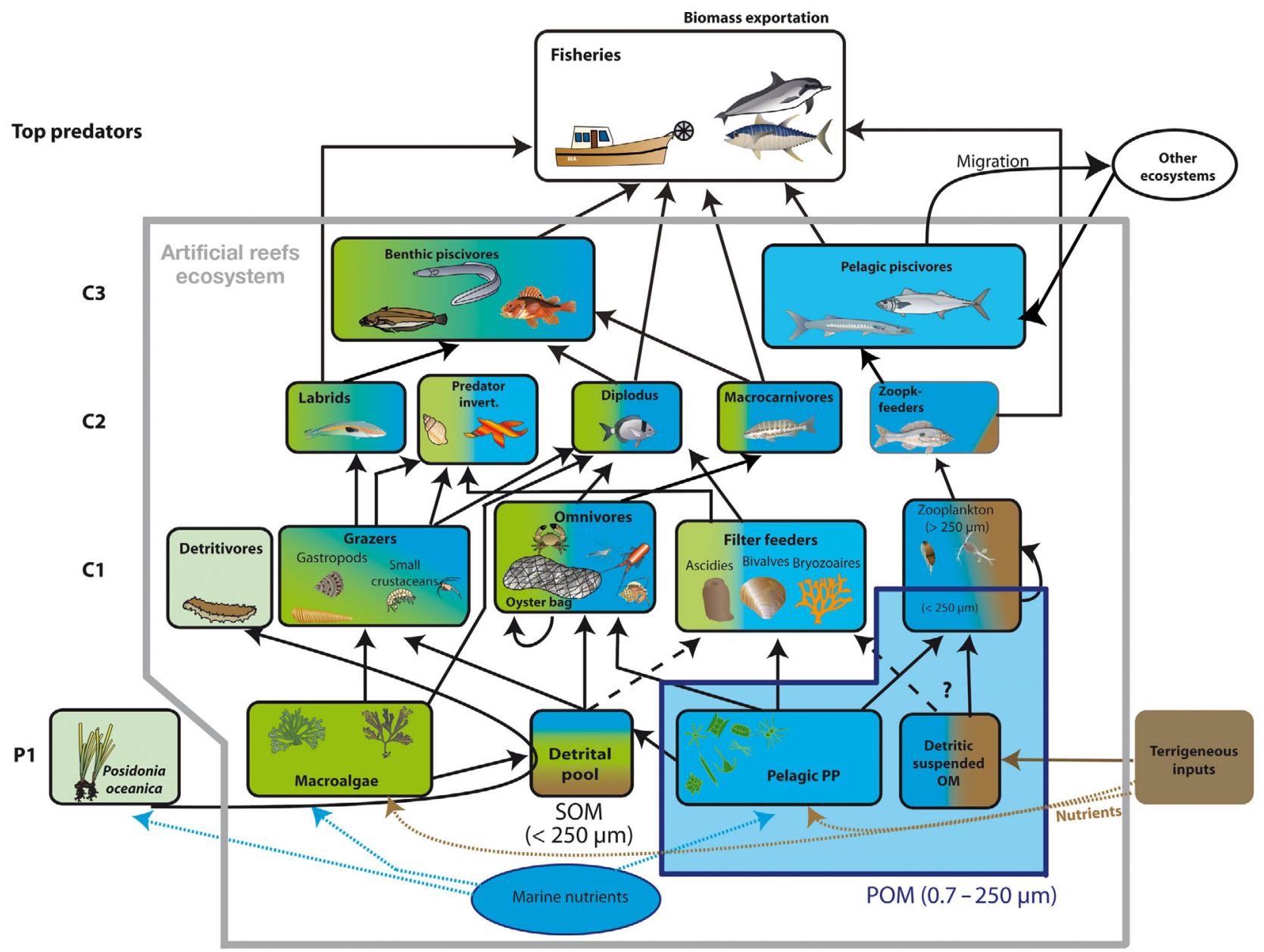

Fig. 5. Conceptual model of the trophic network of the Marseilles Bay artificial reefs. Sizes of arrows or boxes are not proportional to flux intensity or group dominance. Box color indicates the importance of each pathway supporting this group (green: benthic; blue: pelagic; brown: terrestrial). The larger grey box indicates the AR ecosystem. Dashed arrows represent inorganic nutrient fluxes. Symbols courtesy of the Integration and Application Network (http://ian.umces.edu/symbols/)
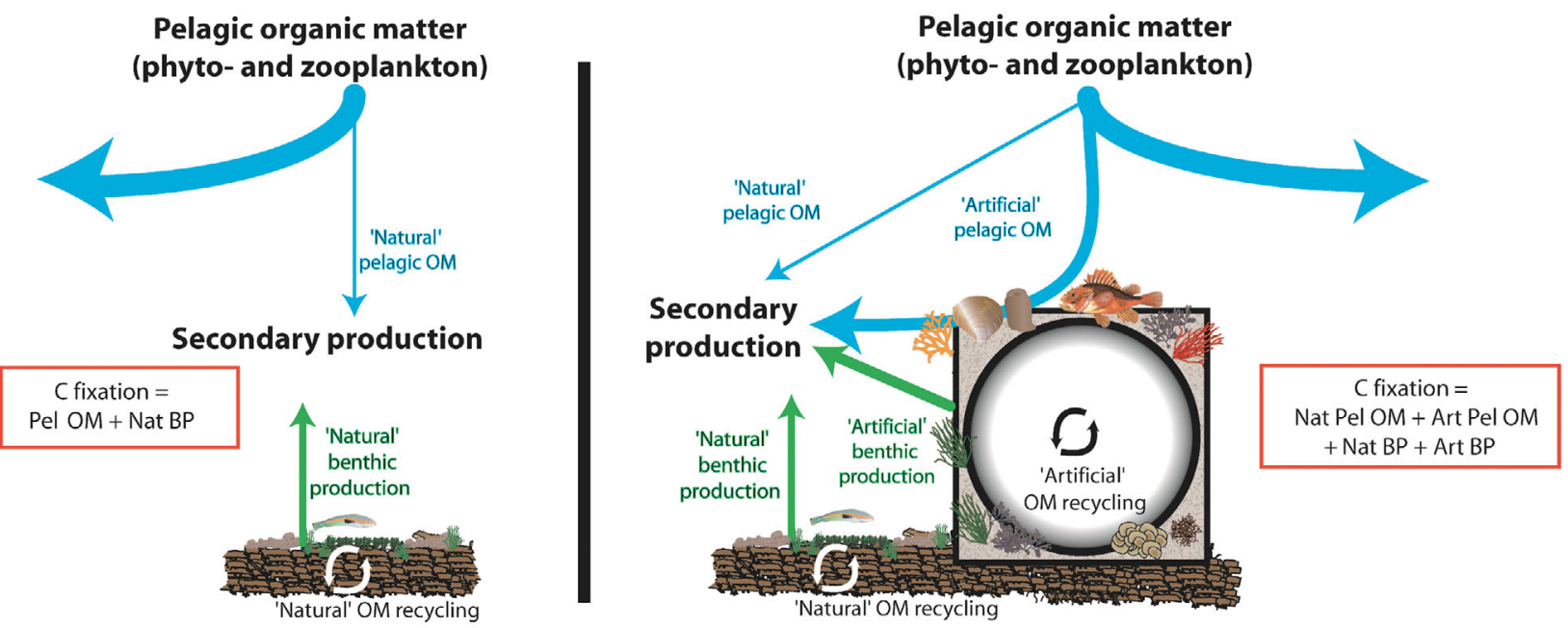

Fig. 6. Theoretical comparison of mechanisms involved in carbon fixation in the Posidonia oceanica dead matte ecosystem before artificial reef deployment ('natural', left) and after deployment ('artificial', right). BP: benthic production; Pel OM: pelagic organic matter. Symbols courtesy of the Integration and Application Network (http://ian.umces.edu/symbols/) 
network. Species such as Marthasterias glacialis or Hexaplex trunculus are considered to be predators of mollusks (Morton et al. 2007), whereas Palaemon spp. are predators of small crustaceans (Guerao 1995). Their respective isotopic positions were consistent with predatory diets, based on the pelagic pathway when feeding on filter feeders, and/or the benthic pathway when preying on grazers. The role of ARs as a food provider for fishes was previously demonstrated in Marseille (Cresson et al. 2014) and elsewhere in the Mediterranean (Relini et al. 2002) from stomach content analyses. The integrative view provided by stable isotope analysis confirmed that fishes belonged to the AR network in spite of differences in feeding behaviors. Benthic carnivorous fishes with sedentary habits, such as Scorpaena spp. or Phycis phycis, are closely dependent on AR production as they directly prey on the small cryptic organisms of the ARs (Relini et al. 2002, Cresson et al. 2014). In contrast, pelagic piscivores with an extensive home range rely only partly on AR resources (Leitão et al. 2008). Nevertheless, the isotopic ratios measured for all fish species, including pelagic piscivores with low site fidelity in reef structures, collected on the ARs of Marseille demonstrated that both primary and secondary production of the ARs supported the increase in fish biomass observed since their deployment (Rouanet et al. 2012).

\section{Assessment of OM fluxes and comparison with other artificial reef systems}

Despite ARs being used worldwide, few studies attempt to assess their whole trophic functioning (Kang et al. 2008, Daigle et al. 2013). With respect to local specificities, their results are consistent with those obtained in Marseille, and confirm the respective role of pelagic and benthic OM pathways in the functioning of all AR systems. The importance of the pelagic production as the main organic matter source in ARs is supported by the general idea that phytoplanktonic production is largely dominant in the world ocean and supports trophic networks even in coastal zones. This idea is reinforced by the predominance of sessile filter feeders among the AR fauna (Bombace et al. 1994, Moura et al. 2006, Nicoletti et al. 2007, Cheung et al. 2010). The importance of the filtering activity on ARs was previously exploited to deploy artificial structures as 'biofilters' under fish farms or in eutrophised environments (Angel \& Spanier 2002). In oligotrophic Mediterran- ean and tropical ecosystems, nanophytoplankton dominates and could be more easily retained by filter feeders, as they mainly retain the predominant fraction of POM (Coma et al. 2001, Grégori et al. 2001, Ribes et al. 2003). The use of picophytoplankton as a food source by hard-bottom filter feeder communities was also observed in Mediterranean (Topçu et al. 2010) and in tropical rocky ecosystems (Ribes et al. 2003). Due to the trophic plasticity of filter feeders, the fraction of the planktonic OM supporting an AR trophic network depends on the nature of the environment (oligotrophic or eutrophic), the relative abundance of filter-feeding species and POM composition.

Benthic primary production is also a source of the OM fueling AR trophic networks. This pathway was demonstrated using herbivore exclusion experiments (Bulleri et al. 2000) and stable isotope analyses (Kang et al. 2008). Kang et al. (2008) use ARs to restore a current barren ground previously colonized by large macroalgal beds and find an equal contribution of benthic and pelagic OM to the trophic networks of the artificial structures. In the Mediterranean, the removal of limpets from ARs results in higher filamentous algal cover, suggesting that these gastropods strongly graze on ARs (Bulleri et al. 2000). However, these 2 studies were performed in shallow environments, where benthic primary production is high and macrograzers abundant. In Marseille, the ARs are much deeper, their associated benthic production lower and no macrograzers occur. Thus, in shallow environments pelagic and benthic pathways could be of a similar order of magnitude, while in deeper environments, such as in Marseille, the pelagic pathway dominates.

\section{Implications for future management of natural and artificial rocky substrates}

In the context of global pressure on coastal ecosystems and the extensive use of ARs as restoring tools, the assessment of their trophic functioning is a prerequisite for better management of artificial structures. The results obtained from the Marseille AR system could serve as a reference baseline to apprehend the alteration of its trophic network in terms of community changes. The ARs in the Bay of Marseille are of recent origin, as their deployment was completed in 2008. Long-term surveys of ARs demonstrated that benthic communities, even if always dominated by filter feeders, do change in time, the first settling organisms being gradually 
replaced by others (Nicoletti et al. 2007). AR deployment also influences the adjacent softbottom ecosystems. Altered hydrodynamic conditions, higher predation and higher waste production by AR organisms lead to alteration of the nature and composition of surrounding soft-bottom communities (Danovaro et al. 2002, Cheung et al. 2010, Dewsbury \& Fourqurean 2010, Leitão 2013). Do such alterations induce changes in trophic relationships and AR functioning? Does nitrogen enrichment of benthic primary production (Dewsbury \& Fourqurean 2010) lead to increased herbivory? Could these potential alterations change the relative importance of 'pelagic' and 'benthic' pathways? Data from the present study and previous ones (Cresson et al. 2012, 2014, Rouanet et al. 2012), along with long-term monitoring of a system are crucial in understanding the patterns of change in AR trophic functioning.

Results from stable isotope analyses enabled understanding some of the mechanisms involved in the ecological efficiency of ARs compared to the dead matte ecosystem they were settled on (Fig. 6). By enhancing local retention of pelagic OM and benthic production, ARs clearly enhance bottom-up effects to effectively produce high trophic-level organisms. The conceptual model designed in the present study (Fig. 5) offers one of the first integrated views of the trophic relationships in an AR system. Up to now relationships were assessed for one trophic level only. For example, stomach contents of some fish species demonstrated that they prey on AR fauna (Steimle \& Ogren 1982, Relini et al. 2002, Leitão et al. 2007, Castriota et al. 2012). Similarly, gastropod exclusion confirmed the grazing of benthic primary production on AR (Bulleri et al. 2000). But these studies could not assess what OM sources fuel the fish preys, or what species consume grazers. The use of stable isotope analyses allowed further understanding of the whole trophic role of ARs, from OM sources to consumers. The present study demonstrated 2 pathways linking OM retention or production to the secondary biomass production. This 'bottom-up' effect of ARs (i.e. enhancement of primary production and fluxes of matter up to high trophic levels) is one of the reliable factors justifying production as the mechanism supporting the biomass increase observed around ARs (Lindberg 1997, Leitão 2013). By enhancing the production of fish species of commercial interest, ARs can be considered as efficient tools to sustain small-scale coastal fisheries, even if this idea should also be supported by future fisheries catch assessment.
Using the results of the present study as a base, future work on AR functioning could be directed towards a better assessment of the role of ARs in an integrated management of coastal zones. One of the objectives of ARs, as set up by the accepted definitions, is that they must 'mimic' the features of natural rocky substrates. A robust comparison of the trophic functioning of natural and artificial reefs is thus needed to confirm similar organization. Unfortunately, few data dealing with the trophic functioning of natural Mediterranean reefs are available to perform such a comparison. A similar importance of the pelagic pathway in natural reefs might be presumed, as benthic filter feeders (such as gorgonians or sponges) also predominate in natural reefs. Future work on this topic is needed. Future work should also allow the combination of qualitative data (such as the data obtained in the present study) with quantitative data such as fish biomasses, OM flux intensities or fisheries catches. Combining qualitative and quantitative approaches in AR trophic network analysis would provide a basis for better understanding the functioning of this ecosystem and defining suitable management policies to maintain artisanal fisheries.

The results obtained in this work demonstrate that ARs enhance the amount of OM retained or produced locally and enhance secondary biomass production. In the context of the attraction/production debate raised by the use of ARs as a tool to support small-scale fisheries, the results clearly demonstrate that deployment of ARs can enhance the biomass of commercial fish species and thus may sustainably support fisheries if well-managed. To this aim, future work should include quantitative approaches (fish biomass or fisheries catch assessment) and should be dedicated towards understanding how ARs can be included in the integrated management of coastal zones, using both natural and artificial reefs.

Acknowledgements. This work was done as part of P.C.'s $\mathrm{PhD}$ thesis and was part of the scientific surveys performed in the 'RECIFS PRADO' program, with financial support from the City of Marseille and the 'Agence de l'Eau Rhône Méditerranée Corse'. We are grateful to all the people who helped during sampling, isotopic analyses or discussions: M. F. Fontaine, M. Ourgaud, F. Morat, B. De Ligondes, F. Zuberer, G. Bleton, C.F. Boudouresque, M. Verlaque (AixMarseille Université, OSU Pytheas), L. Le Diréach, E. Rouanet, P. Astruch, (GIS Posidonie), J. Y. Jouvenel (P2A Développement), P. Richard, G. Guillou (Université La Rochelle). The map of the deployment zone (Fig. 1) was drawn by A. Goujard (GIS Posidonie). We are also grateful to M. Paul, native English speaker, for English correction of a previous version of this paper. Finally, we thank 2 anonymous reviewers for their extensive reviews and constructive comments on a previous version of the manuscript. 


\section{LITERATURE CITED}

Angel DL, Spanier E (2002) An application of artificial reef to reduce organic enrichment caused by net-cage fish farming: preliminary results. ICES J Mar Sci 59:S324S329

Baine M (2001) Artificial reefs: a review of their design, application, management and performance. Ocean Coast Manag 44:241-259

Bănaru D, Harmelin-Vivien M, Boudouresque CF (2010) Man induced change in community control in the northwestern Black Sea: the top-down bottom-up balance. Mar Environ Res 69:262-275

Boecklen WJ, Yarnes CT, Cook BA, James AC (2011) On the use of stable isotopes in trophic ecology. Annu Rev Ecol Evol Syst 42:411-440

Bohnsack JA (1989) Are high densities of fishes at artificial reefs the result of habitat limitation or behavioral preferences? Bull Mar Sci 44:631-645

Bombace G, Fabi G, Fiorentini L, Speranza S (1994) Analysis of the efficacity of artificial reefs located in five different areas of the Adriatic sea. Bull Mar Sci 55:559-580

Boudouresque CF, Bernard G, Bonhomme P, Charbonnel E and others (2012) Protection and conservation of Posidonia oceanica meadows. RAMOGE and RAC/SPA, Tunis

Brickhill MJ, Lee SY, Connolly RM (2005) Fishes associated with artificial reefs: attributing changes to attraction or production using novel approaches. J Fish Biol 67:53-71

Bulleri F, Menconi M, Cinelli F, Benedetti-Cecchi L (2000) Grazing by two species of limpets on artificial reefs in the Northwestern Mediterranean. J Exp Mar Biol Ecol 255: $1-19$

- Castriota L, Falautano M, Finoia M, Consoli P and others (2012) Trophic relationships among scorpaeniform fishes associated with gas platforms. Helgol Mar Res 66:401411

Charbonnel E, Serre E, Ruitton S, Harmelin JG, Jensen AC (2002) Effects of increased habitat complexity on fish assemblages associated with large artificial reef units (French Mediterranean coast). ICES J Mar Sci 59: S208-S213

Charbonnel E, Harmelin JG, Carnus F, Le Direac'h L, Ruitton S, Lenfant P, Beurois J (2011) Artificial reefs in Marseille (France, Mediterranean Sea): from complex natural habitat to concept of efficient artificial reef design. Braz J Oceanogr 59:177-178

Cheung SG, Wai HY, Shin PKS (2010) Fatty acid profile of benthic environment associated with artificial reef in subtropical Hong Kong. Mar Pollut Bull 60:303-308

> Claudet J, Pelletier D (2004) Marine protected areas and artificial reefs: a review of the interactions between management and scientific studies. Aquat Living Resour 17:129-138

Coma R, Ribes M, Gili JM, Hughes RN (2001) The ultimate opportunists: consumers of seston. Mar Ecol Prog Ser 219:305-308

Cresson P, Ruitton S, Fontaine MF, Harmelin-Vivien M (2012) Spatio-temporal variation of suspended and sedimentary organic matter quality in the Bay of Marseilles (NW Mediterranean) assessed by biochemical and isotopic analyses. Mar Pollut Bull 64:1112-1121

Cresson P, Ruitton S, Ourgaud M, Harmelin-Vivien M (2014) Contrasting perception of fish trophic level from stomach content and stable isotope analyses: a Mediterranean artificial reef experience. J Exp Mar Biol Ecol 452:54-62
Daigle ST, Fleeger JW, Cowan J Jr, Pascal PY (2013) What is the relative importance of phytoplankton and attached macroalgae and epiphytes to food webs on offshore oil platforms? Mar Coast Fish: Dyn Manag Ecosyst Sci 5:53-64

Danovaro R, Gambi C, Mazzola A, Mirto S (2002) Influence of artificial reefs on the surrounding infauna: analysis of meiofauna. ICES J Mar Sci 59:S356-S362

> Darnaude AM, Salen-Picard C, Polunin NVC, HarmelinVivien M (2004) Trophodynamic linkage between river runoff and coastal fishery yield elucidated by stable isotope data in the Gulf of Lions (NW Mediterranean). Oecologia 138:325-332

> Dewsbury BM, Fourqurean JW (2010) Artificial reefs concentrate nutrients and alter benthic community structure in an oligotrophic, subtropical estuary. Bull Mar Sci 86: 813-829

Eklund AM (1997) The importance of post-settlement predation and reef resource limitation on the structure of reef fish assemblages. In: Lessios HA, Macintyre IG (eds) 8th International Coral Reef Symposium, Vol 2. Smithsonian Tropical Research Institute, Panama, p 1139-1142

Gorham JC, Alevizon WS (1989) Habitat complexity and the abundance of juvenile fishes residing on small scale artificial reefs. Bull Mar Sci 44:662-665

Gratwicke B, Speight MR (2005) Effects of habitat complexity on Caribbean marine fish assemblages. Mar Ecol Prog Ser 292:301-310

Grégori G, Colosimo A, Denis M (2001) Phytoplankton group dynamics in the Bay of Marseilles during a 2-year survey based on analytical flow cytometry. Cytometry 44:247-256

Grossman GD, Jones GP, Seaman WJ Jr (1997) Do artificial reefs increase regional fish production? A review of existing data. Fisheries 22:17-23

Guerao G (1995) Locomotor activity patterns and feeding habits in the prawn Palaemon xiphias (Crustacea: Decapoda: Palaemonidae) in Alfacs Bay, Ebro Delta (northwest Mediterranean). Mar Biol 122:115-119

Harmelin JG, Bellan-Santini D (1997) Assessment of biomass and production of artificial reef communities. In: Jensen AC (ed) European Artificial Reef Research, Proceedings of the 1st EARRN conference. Southampton Oceanography Centre, Ancona, p 305-322

> Jackson JBC, Kirby M, Berger W, Bjorndal K and others (2001) Historical overfishing and the recent collapse of coastal ecosystems. Science 293:629-637

Jennings S, Kaiser MJ (1998) The effects of fishing on marine ecosystems. In: Blaxter JHS, Southward AJ, Tyler PA (eds) Advances in marine biology, Book 34. Academic Press, London, p 201-352

Jensen A (1998) European artificial reef research network (EARRN): final report and recommendations. University of Southampton

Kang CK, Choy EJ, Son Y, Lee JY, Kim JK, Kim Y, Lee KS (2008) Food web structure of a restored macroalgal bed in the eastern Korean peninsula determined by $\mathrm{C}$ and $\mathrm{N}$ stable isotope analyses. Mar Biol 153:1181-1198

Layman CA, Araujo MS, Boucek R, Hammerschlag-Peyer $\mathrm{CM}$ and others (2012) Applying stable isotopes to examine food-web structure: an overview of analytical tools. Biol Rev Camb Philos Soc 87:545-562

> Leitão F (2013) Artificial reefs: from ecological processes to fishing enhancement tools. Braz J Oceanogr 61:77-81

> Leitão F, Santos MN, Monteiro CC (2007) Contribution of 
artificial reefs to the diet of the white sea bream (Diplodus sargus). ICES J Mar Sci 64:473-478

Leitão F, Santos MN, Erzini K, Monteiro CC (2008) The effect of predation on artificial reef juvenile demersal fish species. Mar Biol 153:1233-1244

Leleu K (2012) Suivi et évaluation de la pêche professionelle au sein d'une Aire Marine Protégée: protocoles d'enquêtes et indicateurs de pressions et d'impacts. Application au Parc Marin de la Côte Bleue. PhD thesis, AixMarseille Université, Marseille

Leleu K, Pelletier D, Charbonnel E, Letourneur Y, Alban F, Bachet F, Boudouresque CF (2014) Métiers, effort and catches of a Mediterranean small-scale coastal fishery: The case of the Côte Bleue Marine Park. Fish Res 154:93-101

Lindberg WJ (1997) Can science resolve the attraction-production issue? Fisheries 22:10-13

Maechler M, Rousseeuw P, Struyf A, Hubert M, Kornick K (2013) cluster. Cluster Analysis Basics and Extension. R package version 1.14.4. http://cran.r-project.org/web/ packages/cluster/index.html

Morton B, Peharda M, Harper EM (2007) Drilling and chipping patterns of bivalve prey predation by Hexaplex trunculus (Mollusca: Gastropoda: Muricidae). J Mar Biol Assoc UK 87:933-940

Moura A, Boaventura D, Cùrdia J, Santos MN, Monteiro CC (2006) Biomass production of early macrobenthic communities at the Faro/Ancão artificial reef (Portugal): effect of depth and reef layer. Bull Mar Sci 78:83-92

Nadon MO, Himmelman JH (2006) Stable isotopes in subtidal food webs: Have enriched carbon ratios in benthic consumers been misinterpreted? Limnol Oceanogr 51: 2828-2836

Nicoletti L, Marzialetti S, Paganelli D, Ardizzone GD (2007) Long-term changes in a benthic assemblage associated with artificial reefs. Hydrobiologia 580:223-240

Pauly D, Christensen V, Dalsgaard J, Froese R, Torres F (1998) Fishing down marine food webs. Science 279: 860-863

Pitcher TJ, Seaman W Jr (2000) Petrarch's principle: how protected human-made reefs can help the reconstruction of fisheries and marine ecosystems. Fish Fish 1:73-81

Polovina JJ (1989) Artificial reefs: nothing more than benthic fish aggregators. CCOFI Rep 30:37-39

Post DM (2002) Using stable isotopes to estimate trophic position: models, methods, and assumptions. Ecology 83: 703-718

Powers SP, Grabowski JH, Peterson CH, Lindberg WJ (2003) Estimating enhancement of fish production by offshore artificial reefs: uncertainty exhibited by divergent scenarios. Mar Ecol Prog Ser 264:265-277

Editorial responsibility: Konstantinos Stergiou, Thessaloniki, Greece
R Development Core Team (2012) R: a language and environment for statistical computing. R foundation for Statistical computing, Vienna. www.r-project.org

Ramos J, Santos MN, Whitmarsh D, Monteiro CC (2007) Stakeholder perceptions regarding the environmental and socio-economic impacts of the Algarve artificial reefs. Hydrobiologia 580:181-191

Rau GH, Teyssie JL, Rassoulzadegan F, Fowler SW (1990) ${ }^{13} \mathrm{C} /{ }^{12} \mathrm{C}$ and ${ }^{15} \mathrm{~N} /{ }^{14} \mathrm{~N}$ variations among size-fractionated marine particles: implications for their origin and trophic relationships. Mar Ecol Prog Ser 59:33-38

Relini G, Relini M, Torchia G, De Angelis G (2002) Trophic relationship between fishes and an artificial reef. ICES J Mar Sci 59:S36-S42

- Ribes M, Coma R, Atkinson MJ, Kinzie RA III (2003) Particle removal by coral reef community: picoplankton is a major source of nitrogen. Mar Ecol Prog Ser 257:13-23

Riisgård H, Larsen P (2010) Particle capture mechanisms in suspension-feeding invertebrates. Mar Ecol Prog Ser 418:255-293

Rouanet E, Astruch P, Le Diréach L, Bonhomme D, Bonhomme P (2012) Opération Récifs Prado: Suivi scientifique, biologique et technique dans la zone d'immersion (suvi obligatoire). Rapport annuel 2012. Résultats. GIS Posidonie - Ville de Marseille, Marseille

Scarcella G, Grati F, Polidori P, Domenichetti F, Bolognini L, Fabi G (2011) Comparison of growth rates estimated by otolith reading of Scorpaena porcus and Scorpaena notata caught on artificial and natural reefs of the northern Adriatic Sea. Braz J Oceanogr 59:32-42

Schaal G, Riera P, Leroux C (2012) Food web structure within kelp holdfast (Laminaria): a stable isotope study. Mar Ecol 33:370-376

Seaman W (2007) Artificial habitats and the restoration of degraded marine ecosystems and fisheries. Hydrobiologia 580:143-155

Seaman W Jr, Jensen AC (2000) Purpose and practices of artificial reef evaluation. In: Seaman W Jr (ed) Artificial reef evaluation with application to natural habitats. Taylor \& Francis, Boca Raton, FL, p 1-21

Steimle FL, Ogren L (1982) Food of fish collected on artificial reefs in the New York bight and off Charleston, South Carolina. Mar Fish Rev 44:49-52

Tessier A, Verdoit-Jarraya M, Blouet S, Dalias N, Lenfant P (2014) A case study of artificial reefs as a potential tool for maintaining artisanal fisheries in the French Mediterranean Sea. Aquat Biol 20:255-272

Topçu NE, Perez T, Grégori G, Harmelin-Vivien M (2010) In situ investigation of Spongia officinalis (Demospongiae) particle feeding: coupling flow cytometry and stable isotope analysis. J Exp Mar Biol Ecol 389:61-69

Submitted: January 10, 2014; Accepted: May 14, 2014 Proofs received from author(s): August 11, 2014 